Doi: https://doi.org/10.31578/jebs.v6i1.221

\title{
An Experiment on Teaching English as a Foreign Language in Romanian Schools Using Mastery Learning Strategies
}

Irina Vlădescu*

Publishing current paper was financed through "Entrepreneurial Education and Professional Counseling for Social and Human Sciences PhD and Postdoctoral Researchers to ensure knowledge transfer from the field of Social Sciences and Humanities to the Labor Market" project, co-financed from European Social Fund through Human Capital Programme (ATRiUM, POCU/380/6/13/123343)

\begin{abstract}
The last 29 years of education in the democratic system in Romania have shown that the use of mastery learning strategies is not present in our nowadays teaching-learning process. Even though studies were carried out to show the effectiveness of these strategies teachers still feel reluctant whether to implement a mastery learning model or not. The subject emphasized in this paper is related to the implementation of a mastery learning strategy during the teaching of English as a second language in a public school in Bucharest, Romania.
\end{abstract}

Keywords: education, mastery learning, Romanian schools, knowledge, learning strategies

\section{Introduction}

This study was based on the acknowledgement that one of the consequences of students' poor school performance might be the lack of efficient educational strategies in the Romanian educational system. The last report made by the Ministry of National Education in Romania was released in 2018 and it analyzed the Romanian education system between 2009 and 2018. The report mainly involved statistical analysis of the education system and was based on indicators such as the number of students who are registered in schools, teachers and other human resources, students' results, and the number of students who succeed in getting a job after finishing school (Ministry of National Education, 2018). According to this report, the number of students who finished secondary school $\left(5^{\text {th }}-8^{\text {th }}\right.$ grades, students aged $\left.11-15\right)$ decreased from $94 \%$ in 2009 to $80.7 \%$ in 2017.

Another report, by the European Commission (2015), has revealed the fact that Romania is still one of the countries where the results in the tests implemented through OECD's Programme for International Student Assessment (PISA) are unsatisfactory. In 2015, one student out of 4 did not manage to reach level 2 of performance in Romanian, mathematics and science which was the minimum level to be reached by the end of the $8^{\text {th }}$ grade. The same report mentioned the fact that there has been no improvement in the 2015 tests. The results were similar to the ones obtained in 2009 and 2012 tests.

* Ph. D, University of Bucharest, Faculty of Psychology and Educational Sciences, Bucharest, Romania 
Even though these assessments only regard reading comprehension, mathematics and science, the other subjects are also to be considered in the overall performance of a student. And the data related to the decreasing number of students who finish the $8^{\text {th }}$ grade is of great importance in stating that something needs to be changed in the Romanian education system.

One more report by the European Commission revealed similar outcomes. Around $40.4 \%$ of the 15 -year-old students could not reach the minimum level of performance in reading, mathematics, and science in 2009 and $38.7 \%$ of them could not reach this level in 2018. Even though the number of students who obtained poor results slightly decreased, the problems they are dealing with are the same (European Commission, 2019).

\section{Literature review}

The learning models which John B. Carroll and Benjamin S. Bloom advocated for in the 1960s and the results of so many researches (Abu Moumer, 2017; Amirrudin \& Zainudin, 2015; Aviles, 2001; Birhan, 2018; Elaldı, 2016; Hill-Miller, 2011; Kazu et al., 2005; Mehar \& Kanwar, 2019; Moyosore, 2015; Sooyoung, 2005; Thompson \& Grabau, 2005) in this area determined the researcher to adapt the initial model and implement it during English as a second language classes.

The phrase mastery learning was not new in the educational system of the United States of America. It has been known since the 1920s when Carleton Washburne (1925; Washburne et al., 1926), a superintendent in Winnetka, decided to improve the results of the students by letting them learn at their own pace, individually or in groups. These students were allowed to organize their own learning and to learn everything in their own manner until they proved mastery of the contents.

Carroll and Bloom stated that all children can learn if they are provided with the right learning conditions. In 1963 John B. Carroll developed a learning model in which each student can acquire what he/she is supposed to as long as he/she is provided with the proper learning conditions. Needless to say, the students who are successful as a result of being involved in a mastery learning strategy are supposed to have the inner ability to learn.

John B. Carroll's model of school learning was based on the efficient use of time dedicated to learning. He stated that students' outcomes are influenced by the ratio between the time needed to learn and the time spent on learning (Carroll, 1963).

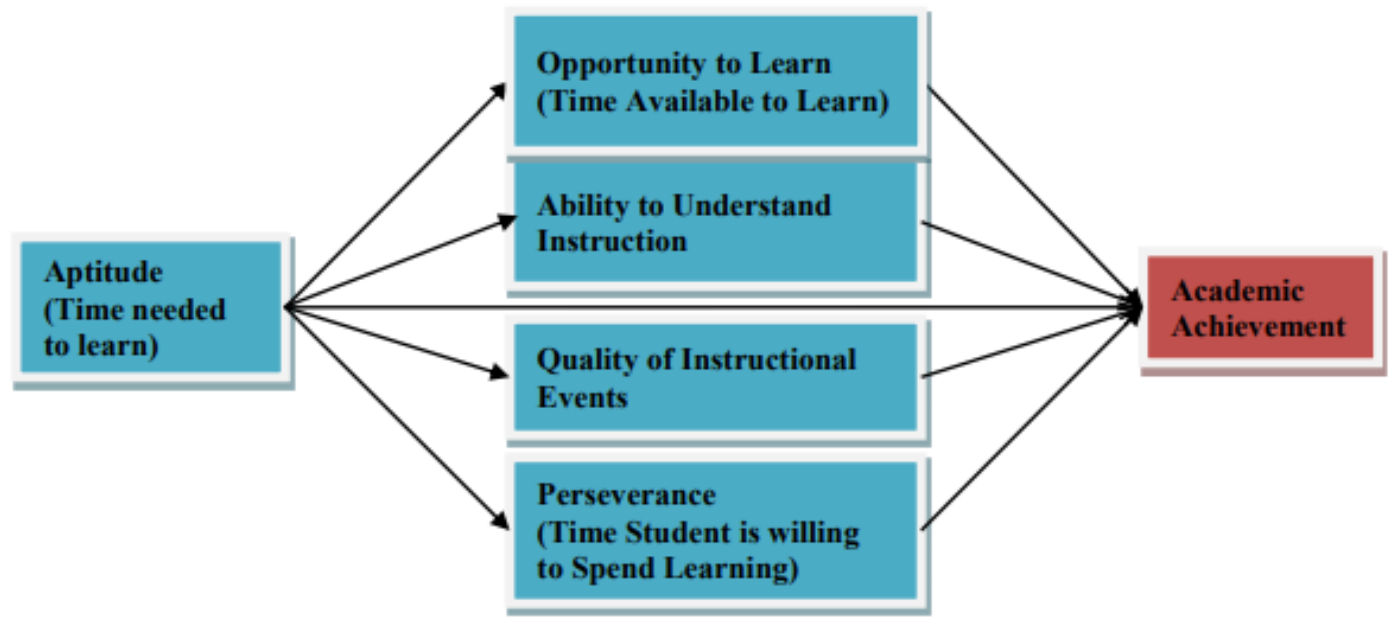

Figure 1. Carroll's Model of Mastery Learning (cited from Rintaningrum, 2018, p. 1) 
According to Carroll (1963) and Bloom (1968), there are five variables of the mastery learning strategies which are related to time and knowledge. The first is aptitude (the time needed by the student to learn new contents). The second is the opportunity to learn (the time given to a student to learn). During the regular time allocated to a class (45 or 50 minutes), the teacher must teach new contents, the students have to complete some activities and exercises and their understanding has to be checked. Some students are faster than others and that is why some of them may not have enough time to master the material during a regular class. The perseverance (the time a student is willing to spend learning) is the third characteristic of a mastery learning model. The fourth aspect refers to the quality of the instructional process (the way the teacher presents the new information and explains the requirements). The fifth feature is related to the understanding of requirements (Bloom, 1968). Besides the five variables needed to be taken into consideration in the teaching-learning process, Carroll mentioned the essential factors which influence the desired outcomes in this process: selecting essential content from the given syllabus (it depends on each teacher what he/she considers to be essential content), organizing this content into learning units, setting the objectives for each of these units, creating and applying formative assessments at the end of each unit, providing feedback, and also completing some supplementary tasks (to overcome difficulties in learning or to broaden one's knowledge). This model implies not only learning some specific content but also finding the means through which a student can learn. The initial teaching should be the same for all students, but the supplementary tasks should be adapted to the needs of each student. Implementing this strategy implies an initial assessment and a final assessment to check students' progress (Carroll, 1963).

Mastery learning models the aim to overcome individual differences between students by using techniques and tools that will give them the same chance to succeed.

On the other hand, Bloom's model added some extra stages to Carroll's learning strategy. The quality of instruction (the appropriate tools, explanations, instructions, methods used by the teacher during the teaching process in order to make students reach their full potential in learning) and the students' interest in learning are the two key elements of his model (Bloom, 1968). Bloom also emphasized the need to adapt the instruction to the characteristics of at least each group of students if not of every student. His model is mainly based on his taxonomy of educational learning objectives. He stated that each learning unit should be hierarchically organized beginning with simple tasks such as understanding simple contents and information and continuing with completing more difficult tasks that imply critical thinking, using ideas and concepts in new contexts, analyzing the learnt information, evaluating, and using one's creative skills (Bloom, 1956). Learning objectives must be stated by the teacher at the beginning of each learning unit for the student to know what he must learn in that unit.

The use of formative assessments, feedback, and remedial activities is of great importance in assuring the success in learning. Formative assessments should be a part of the teaching-learning process used as a tool to measure progress and should not be used only for finding out students' results and providing them with a positive or a negative sanction (Radu, 2007). The feedback, the remedial activities, and the chance to succeed in a second formative assessment might motivate students to remain engaged in the learning process.

Bloom stated that if all children are provided with the right learning conditions, almost all of them (around 90\%) can learn properly (Bloom, 1968). To support this idea, Bloom conducted some studies in which he observed the positive effect of using mastery learning strategies in one-to-one tutoring, on the one hand (Bloom's two sigma problem) and, on the other hand, he and his students studied the positive effect of combining different variables related to mastery learning. A research conducted by two of Bloom's graduate students, Anania $(1982,1983)$ and Burke (1984), revealed the fact that students who had similar "initial aptitude test scores, previous achievement in the subject, and initial attitudes and interest in the subject" (Bloom, 1984, p. 4) learnt 
differently in the three assigned groups: a group where the teaching was conventional, a group where mastery learning strategies were implemented, and a group where each student learnt with the help of a tutor. Bloom (1984) stated the following:

Using the standard deviation of the control class, it was found that the average student under tutoring was about two standard deviations above the average of the control class, and the average student under mastery learning was about one standard deviation above the average of the control class. (p. 4)

The studies Bloom mentioned had important findings related to the role of providing the appropriate learning conditions: Leyton's (1983) findings revealed that $50 \%$ of the students learnt well in a conventional class, $76 \%$ learnt well in a conventional class when they also improved their initial knowledge in the subject matter, $84 \%$ performed well under mastery learning conditions, and 95\% performed well under mastery learning conditions and improved initial knowledge. In Anania and Burke's studies, students reached the required level as follows: $50 \%$ in conventional classes, $84 \%$ in mastery learning classes, and $98 \%$ in tutoring classes (Bloom, 1984).

So, the mastery learning model implies the successful process of teaching, learning and evaluating a student who can reach his highest potential as long as he/she has sufficient time and the necessary learning conditions such as a good instruction, a good understanding of the activities and requirements, and the support for completing his tasks.

The teaching-learning process implies not only learning for mastery techniques, but also teaching for mastery techniques (Block \& Burns, 1976). Under the right learning conditions, a student is supposed to learn everything and the teacher must make sure he/she is using the appropriate method to help students reach their objectives.

In applying mastery learning strategies, a teacher must know each student, his/her learning possibilities, needs and requirements, and has to provide qualitative instruction, optimal learning conditions and enough time for the student to learn.

Mastery learning is different from other successful forms of learning because it implies a combination between a conventional class/process of teaching and learning and an effective one-to-one tutoring process. This means that the benefits of one-to-one tutoring are transferred to a conventional class where the student-teacher ratio is about 30:1. The methods used in applying mastery learning models are the ones that really matter and are the only variables that need to be changed (not the time allocated for learning, the number of students and of teachers in a class or the content needed to be learnt). These methods involve mainly a coherent and clear organization of the teaching-learning process. All mastery learning strategies can be adapted to the characteristics of each group of students. A basic scheme for a mastery learning strategy can be the following: initial assessment, defining the learning unit, stating the objectives, teaching the content, completing the given learning tasks, applying formative assessment, completing enhancement or remedial activities, applying a second formative assessment, providing feedback, moving on to a new learning unit, and applying a summative assessment at the end of all units to check students' progress. Formative assessments allow students to identify their weaknesses and their knowledge gaps and try to overcome them using some other means. Students cannot move to another learning unit if they do not prove they have reached the minimum level of performance.

In Romanian schools, mastery learning strategies have been applied only in the 1980s by Vasile Bunescu (1995), loan Jinga, and lon Negreț (1994). The results gathered from their researches showed that the model was efficient and that the children learnt more and were more involved in the teaching process. Although the outcomes were positive, their experiments did not have an impact on the national educational system because the research was limited to a few schools.

Vasile Bunescu's experiment was conducted in subjects such as Romanian, mathematics, English, geography, history, and economy, both in primary and secondary schools, and also in high schools between 1981 and 1985 . Students in the $2^{\text {nd }}$ grade 
from Secondary School No. 17 Pitești succeeded in overcoming some of the difficulties they had in learning mathematics. On a grading scale of 1 to 10 , no student failed in learning mathematics, meaning that no student was graded below 5 at the end of the school year even though some of them got grades below 5 in the initial assessment. At the end of the $3^{\text {rd }}$ grade, all marks were above 7, implying a positive effect of implementing this learning model. At Secondary School No. 2 in Slobozia, the overall average in second-grade mathematics increased from 6.40 to 8.20 on a scale of 1 to 10 . At Secondary School No. 1 in the same city the overall average in sixth-grade Romanian increased from 6.20 to 8.30 on a scale of 1 to 10 by the end of the school year. In the same school, the overall average in fifth-grade Romanian increased from 5.20 in the initial assessment to 6.90 in the final assessment (Bunescu, 1995).

Ion Negreț and loan Jinga's quasi-experiment was conducted in seven middle schools $\left(5^{\text {th }}-8^{\text {th }}\right.$ grades, students aged $11-$ $15)$ and three high schools $\left(9^{\text {th }}-12^{\text {th }}\right.$ grades, students aged 15-19) in Bucharest. Their learning model had the following structure: initial assessment, learning objectives for each unit, formative assessment, feedback, remedial or enrichment activities, a second formative assessment, and a summative assessment at the end of all units (Jinga \& Negreț, 1994). This quasi-experiment was meant to contribute to the filling of knowledge gaps and to help students reach the minimum level of performance (to be graded at least 5). Some of the results of their research are to be found in the following table.

Table 1. Results of the quasi-experiment (Jinga \& Negreț, 1994)

\begin{tabular}{|c|c|c|c|c|}
\hline Subject & School & Grade & $\begin{array}{l}\text { Initial assessment } \\
\text { Grades below } 5\end{array}$ & Final assessment \\
\hline \multirow[t]{3}{*}{ Romanian } & School No. 139 & $5^{\text {th }}$ & $58.8 \%$ & $10.8 \%$ \\
\hline & School No. 139 & $6^{\text {th }}$ & $27 \%$ & $5.8 \%$ \\
\hline & High School No. 27 & $10^{\text {th }}$ & $20 \%$ & $0 \%$ \\
\hline \multirow[t]{3}{*}{ Mathematics } & School No. 207 & $5^{\text {th }}$ & $30 \%$ & $2 \%$ \\
\hline & High School No. 9 & $7^{\text {th }}$ & $33 \%$ & $4 \%$ \\
\hline & High School No. 9 & $9^{\text {th }}$ & $31.42 \%$ & $0 \%$ \\
\hline \multirow[t]{2}{*}{ Physics } & High School No. 9 & $10^{\text {th }}$ & $32 \%$ & $4 \%$ \\
\hline & High School No. 9 & $11^{\text {th }}$ & $38 \%$ & $0 \%$ \\
\hline Foreign & High School No. 1 & $9^{\text {th }}$ & $84 \%$ & $0 \%$ \\
\hline languages & High School No. 1 & $10^{\text {th }}$ & $80 \%$ & $0 \%$ \\
\hline
\end{tabular}

The differences between the results obtained in the initial assessments and the ones from the summative assessments were significant.

Table 2. Differences between experimental groups and control groups in the initial and final assessments (Jinga \& Negreț, 1994)

\begin{tabular}{|c|c|c|c|c|c|}
\hline Subject & School & $\begin{array}{l}\text { Overall } \\
\text { assessment }\end{array}$ & initial & $\begin{array}{l}\text { Overall average } \\
\text { assessment }\end{array}$ & summative \\
\hline & & $\begin{array}{l}\text { Experimental } \\
\text { group }\end{array}$ & $\begin{array}{l}\text { Control } \\
\text { group }\end{array}$ & Experimental group & $\begin{array}{l}\text { Control } \\
\text { group }\end{array}$ \\
\hline \multirow[t]{3}{*}{ Mathematics } & High School No. 9 & 5.79 & 5.90 & 7.50 & 6.30 \\
\hline & High School No. 1 & 4.40 & 4.30 & 7.53 & 5.09 \\
\hline & School No. 96 & 5.14 & 5.20 & 7.75 & 5.15 \\
\hline French & School No. 139 & 7.73 & 6.04 & 8.31 & 6.64 \\
\hline Romanian & School No. 20 & 5.56 & 5.28 & 7.83 & 5.52 \\
\hline Physics & School No. 20 & 6.80 & 6.37 & 7.84 & 6.42 \\
\hline
\end{tabular}


The number of students who could not be graded at least 5 in Romanian and mathematics decreased or disappeared. Consequently, the number of students who succeeded in getting grades above 5 increased as shown in table 3 .

Table 3. Relevant results in Romanian and mathematics (Jinga \& Negreț, 1994)

\begin{tabular}{|c|c|c|c|c|}
\hline \multirow[t]{2}{*}{ Romanian } & \multirow[t]{2}{*}{ Grade } & \multicolumn{3}{|l|}{ Mark } \\
\hline & & $1-4$ & $5-7$ & 8-10 \\
\hline \multirow[t]{3}{*}{ School No. 96} & 2nd & $0 \%$ & $8.5 \%$ & $91.5 \%$ \\
\hline & $3 r d$ & $0 \%$ & $19.4 \%$ & $80.6 \%$ \\
\hline & 4th & $0 \%$ & $18.8 \%$ & $81.2 \%$ \\
\hline School No. 85 & 6th & $6.5 \%$ & $29 \%$ & $64.5 \%$ \\
\hline High School No. 27 & 10th & $0 \%$ & $42 \%$ & $58 \%$ \\
\hline \multicolumn{5}{|l|}{ Mathematics } \\
\hline \multirow[t]{3}{*}{ School No. 96} & 2nd & $0 \%$ & $8.5 \%$ & $91.5 \%$ \\
\hline & $3 r d$ & $0 \%$ & $17 \%$ & $83 \%$ \\
\hline & 4th & $0 \%$ & $18.3 \%$ & $81.7 \%$ \\
\hline School No. 85 & 6th & $5 \%$ & $31 \%$ & $64 \%$ \\
\hline High School No. 1 & 9th & $9.09 \%$ & $56.91 \%$ & $34 \%$ \\
\hline High School No. 27 & 10th & $3 \%$ & $61 \%$ & $36 \%$ \\
\hline
\end{tabular}

\section{Methodology}

The researcher decided to conduct this experiment to see if the teaching strategies based on the mastery learning model really work. The experiment was conducted in a public school, Ion Heliade Rădulescu Secondary School, in Bucharest, Romania. Two experimental groups and two control groups were selected in order to compare the results and to see if the quality of the teaching-learning process increases if mastery learning strategies are applied.

The school like many other schools in Bucharest, has large classes with up to 40 students. It is quite difficult to make them all learn and understand what the teacher has to teach in 50 minutes.

In this study two classes from the primary school $\left(4^{\text {th }}\right.$ grade, students aged $10-4 \mathrm{C}$ : experimental group; $4 \mathrm{~B}$ : control group) and two classes from the secondary school $\left(6^{\text {th }}\right.$ grade, students aged $12-6$ B: experimental group; 6 A: control group) participated.

The mastery teaching-learning strategy (only for the experimental groups) was planned as follows.

> Students had to undergo an initial assessment to have their level in English checked at the beginning of the teaching sequence. The assessment was based on their previous knowledge required by the syllabus for the first semester and it was chosen according to the requirements of the Common European Framework of Reference for Languages for each level: $\mathrm{A} 2$ for $4^{\text {th }}$ grade and B1 for $6^{\text {th }}$ grade. This initial assessment checked their level regarding the use of vocabulary, correct use of grammar, reading comprehension, spelling, creative writing, and communication skills.

$>$ The content was selected from the national curriculum but the methods and tools used for teaching it belonged to the researcher (an example would be teaching grammar in context and giving up on an old familiar way of translating sentences to learn grammar).

- The time spent on each unit was established.

$>$ The teacher had stated all the educational objectives for each learning unit. 
- $\quad$ Each unit was followed by formative assessment.

> According to the results, the teacher provided each student with appropriate feedback.

$>$ Students who got great scores at the formative assessment, completed some supplementary tasks in order to broaden their knowledge and the ones who did not succeed completed some extra tasks which helped them overcome the difficulties in learning.

$>\quad$ The teaching-learning strategy ended with a summative assessment to see if the results confirm the efficiency of teaching.

The teaching-learning process for the control groups was organized in the so-called traditional way, meaning that the teacher went to the class, presented the contents, the students fulfilled some activities but were never provided with feedback or given another chance to fill in the gaps in their knowledge.

\section{Data Analysis}

The assessments held were the same for both groups, experimental or control, and were based on the learning objectives stated at the beginning of each unit. The progress was measured by comparing the results from the initial assessment with the results from the summative assessment. Although the original mastery learning model implied that the students should retake the formative assessments until they have learnt everything, we adapted it and used the formative assessments only to identify the learning strengths and weaknesses.

\section{Results of Data Analysis}

An initial test developed by the authors of the coursebooks used in class (Welcome 3, Virginia Evans, Elizabeth Gray for $4^{\text {th }}$ grade and Enterprise 2, Virginia Evans, Jenny Dooley for $6^{\text {th }}$ grade) was held. Both tests were in agreement with the requirements of the syllabus for each grade. The same initial assessment was applied over the years (from 2015 to 2018) and the results were similar at the beginning of the second semester for each of the two levels. This assessment showed that the students in the experimental groups and the ones in the control groups had almost the same initial level in English. The results of the initial assessments are shown below.

1. Diagram A

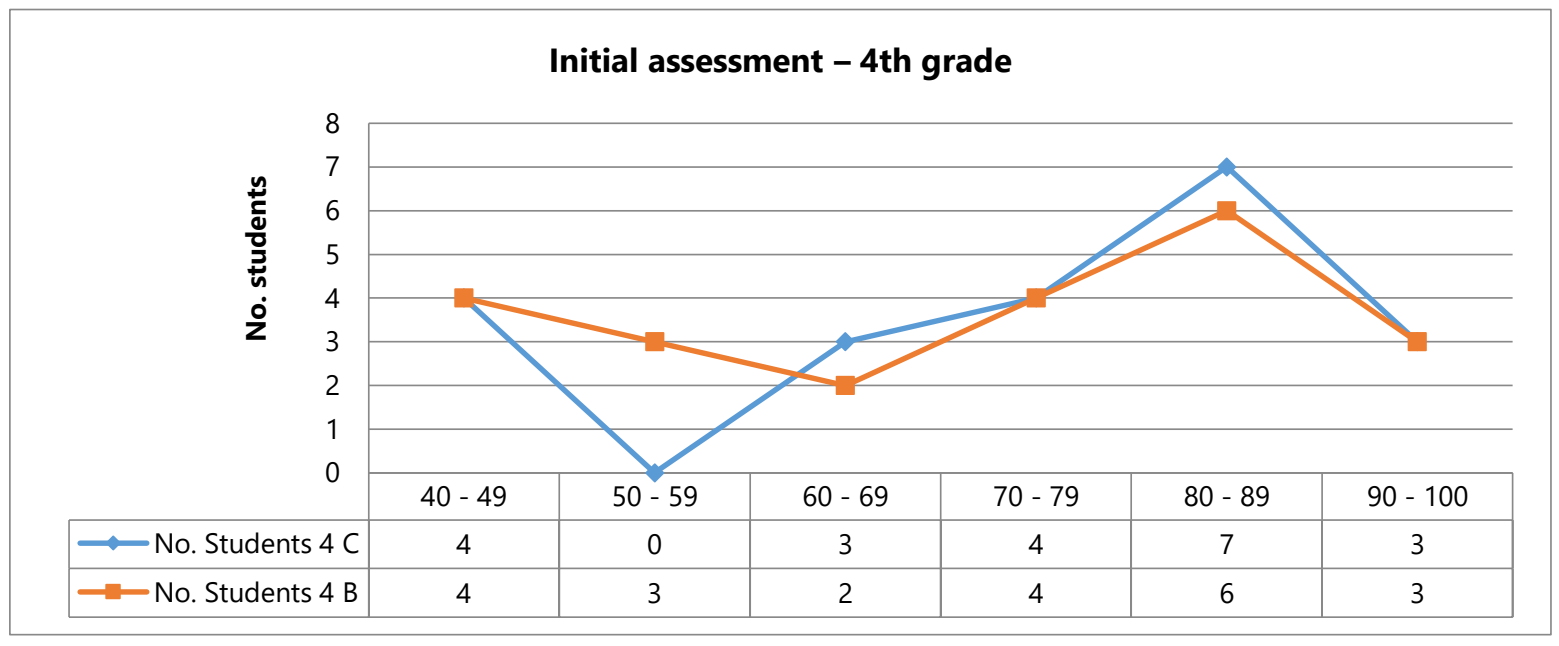


2. Diagram B

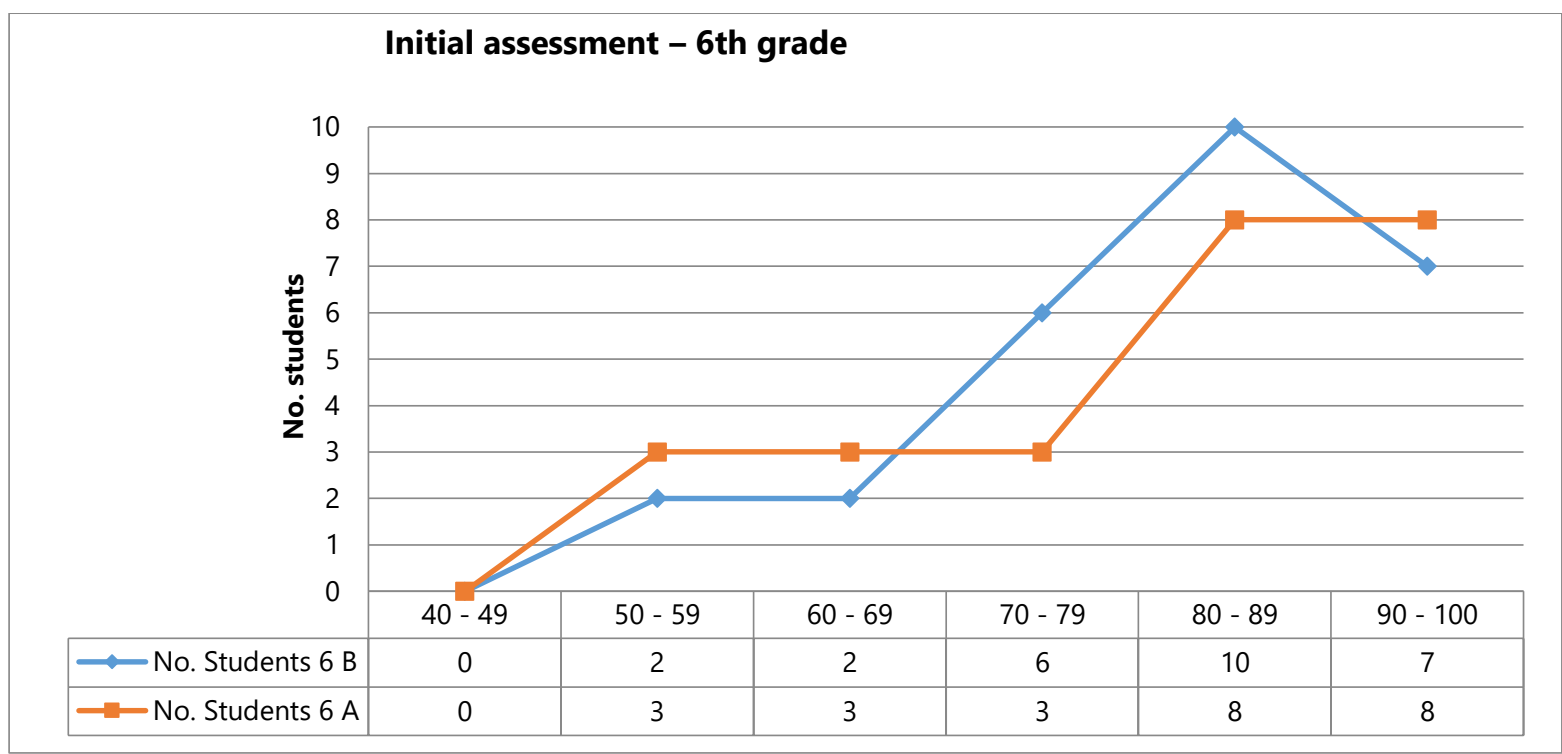

This assessment was followed by the teaching of new materials. Five learning units were chosen for the experiment for each grade. The content of these units was related to the correct use of grammar in context (nouns, adjectives, verb tenses, adverbs), reading comprehension (identifying specific information in a given text, using the information to answer some questions, identifying the correct answers for some items using a text, and using similar information in new contexts), analyzing different pieces of information, and creating new learning contexts in writing. The steps in learning were similar for both experimental groups being of course adapted to the required level of English for each of them.

These units were completed in nine weeks (18 hours) for the $4^{\text {th }}$ grade and eight weeks (16 hours) for the $6^{\text {th }}$ grade. To start the new teaching process, the researcher clearly communicated the learning objectives, presented the information, and involved the children in some learning activities. Next, the students took a formative assessment at the end of each lesson to check their understanding of the new contents.

The formative assessments were followed, as it was mentioned before, by some supplementary activities. There were 5 formative assessments for each group, one at the end of each learning unit. They focused on checking the correct use of grammar in context, reading comprehension (if the students were able to identify and use the information in a given text to complete a true/false item or to answer some questions), and creative writing. These assessments were used to identify the strengths and weaknesses in learning and to create and use the right activities to improve the students' results. They were not used to see the progress that the students make in their learning because they were not related to each other.

The activities that were supposed to help children fill the missing information or enrich their knowledge were applied during classes at school. The results of the formative assessments are to be found in the following tables.

Table 4. Class average - formative assessments, $4^{\text {th }}$ grade

4 C - experimental group; 4 B - control group

\begin{tabular}{|c|c|c|c|c|c|c|c|c|c|}
\hline Test 1 & & Test 2 & & Test 3 & & Test 4 & & Test 5 & \\
\hline $4 \mathrm{C}$ & 4 B & $4 C$ & 4 B & $4 \mathrm{C}$ & 4 B & $4 \mathrm{C}$ & 4 B & $4 \mathrm{C}$ & 4 B \\
\hline 9.06 & 9.20 & 9.30 & 8.64 & 8.42 & 6.72 & 8.75 & 7.09 & 9.28 & 8.80 \\
\hline
\end{tabular}


Table 5. Class average - formative assessments, 6 th grade

6 B - experimental group; 6 A - control group

\begin{tabular}{llllllllll}
\hline Test 1 & & Test 2 & \multicolumn{3}{c}{ Test 3 } & \multicolumn{3}{c}{ Test 4 } & Test 5 \\
\hline 6 B & 6 A & 6 B & 6 A & 6 B & 6 A & 6 B & 6 A & 6 B & 6 A \\
8.62 & 8 & 9.52 & 9.54 & 9.44 & 9.25 & 9.60 & 9.70 & 9.80 & 9.26
\end{tabular}

If the results of the formative assessments were the expected ones, the students completed some additional tasks in order to broaden their knowledge. If the results were not satisfactory, they were engaged in some learning activities that helped them overcome their learning difficulties. Some of the activities used were games, riddles, crosswords, audio-visual materials, and worksheets.

At the end of the experiment, the students had to take a summative assessment in order to see whether they had overcome their learning difficulties and their results had improved.

The comparison between the initial assessments and the summative ones are shown in the following diagrams. The class average for the $4^{\text {th }}$ grade (experimental group) was 7.28 (on a scale of 1 to 10 ) in the initial assessment and it increased to 8.19 in the summative assessment.

3. Diagram C

Initial assessment and summative assessment - 4th grade

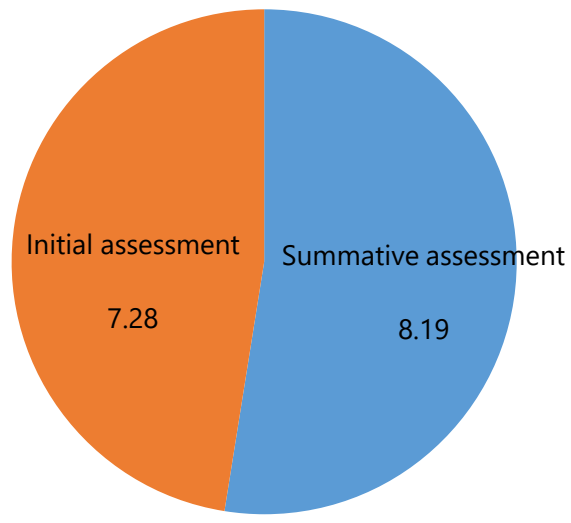

The class average for the $6^{\text {th }}$ grade (experimental group) was 8.12 (on a scale of 1 to 10 ) in the initial assessment and it increased to 8.98 in the summative assessment.

4. Diagram D 


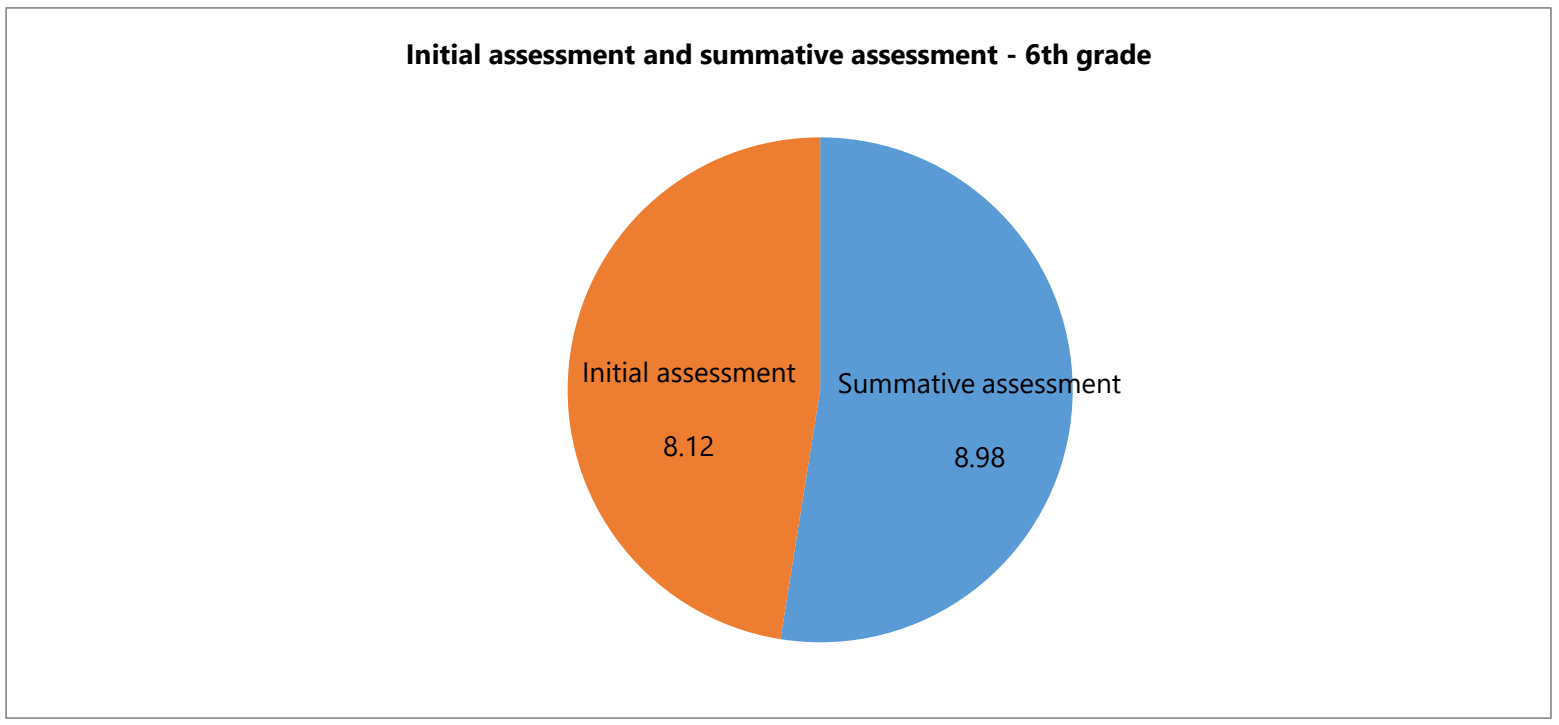

The main difficulties identified in learning for both grades $\left(4^{\text {th }}\right.$ and $\left.6^{\text {th }}\right)$ that were overcome at the end of the learning strategy consisted of not knowing the meaning of some words and phrases, the misuse of some verbs, the wrong match of some communication phrases, the use of elementary vocabulary, and the superficial writing of a text based on some given information.

To see whether the difference between the control and the experimental groups was statistically important, a paired sample t-test was conducted.

Table 6. Independent Samples T-Test $-4^{\text {th }}$ grade

Independent Samples T-Test $-4^{\text {th }}$ Grade

95\% Confidence

Interval

\begin{tabular}{|c|c|c|c|c|c|c|c|c|c|}
\hline & & statistic & df & $\mathbf{p}$ & $\begin{array}{l}\text { Mean } \\
\text { difference }\end{array}$ & $\begin{array}{l}\text { SE } \\
\text { difference }\end{array}$ & Lower & Upper & $\begin{array}{l}\text { Cohen's } \\
\text { d }\end{array}$ \\
\hline Progress & Student's t & 2.92 & 42.00 & 0.006 & 0.77 & 0.27 & 0.24 & 1.31 & 0.88 \\
\hline
\end{tabular}

Table 7. Descriptives $-4^{\text {th }}$ grade

Descriptives $-4^{\text {th }}$ grade

\begin{tabular}{lllll}
\hline & Group & Initial assessment & Summative assessment & Progress \\
\hline $\mathrm{N}$ & Exp. & 21 & 21 & 21 \\
\multirow{3}{*}{ Mean } & Control & 23 & 23 & 23 \\
\multirow{4}{*}{ Median } & Exp. & 7.28 & 8.19 & 0.91 \\
& Control & 7.24 & 7.38 & 0.13 \\
Standard deviation & Exp. & 7.70 & 8.40 & 1.00 \\
& Control & 7.80 & 7.80 & 0.00 \\
& Exp. & 1.66 & 1.34 & 0.93 \\
& Control & 1.79 & 1.93 & 0.84
\end{tabular}


Table 8. Independent Samples T-Test $-6^{\text {th }}$ grade

Independent Samples T-Test $-6^{\text {th }}$ Grade

\begin{tabular}{|c|c|c|c|c|c|c|c|c|c|}
\hline & & & & & & \multicolumn{2}{|c|}{$\begin{array}{l}95 \% \\
\text { Confidence } \\
\text { Interval }\end{array}$} & \multirow[b]{2}{*}{$\begin{array}{l}\text { Cohen's } \\
\text { d }\end{array}$} \\
\hline & & statistic & df & $\mathbf{p}$ & $\begin{array}{l}\text { Mean } \\
\text { difference }\end{array}$ & $\begin{array}{l}\text { SE } \\
\text { difference }\end{array}$ & Lower & Upper & \\
\hline Progress & $\begin{array}{l}\text { Student's } \\
\mathrm{t}\end{array}$ & 2.49 & 50.00 & 0.016 & 0.46 & 0.18 & 0.09 & 0.83 & 0.69 \\
\hline
\end{tabular}

Table 9. Descriptives $-6^{\text {th }}$ grade

Descriptives $-6^{\text {th }}$ grade

\begin{tabular}{|c|c|c|c|c|}
\hline & Group & Initial assessment & Summative assessment & Progress \\
\hline \multirow[t]{2}{*}{$N$} & Exp. & 27 & 27 & 27 \\
\hline & Control & 25 & 25 & 25 \\
\hline Mean & Exp. & 8.13 & 8.65 & 0.53 \\
\hline
\end{tabular}

Table 9 (continued)

$\begin{array}{lllll} & \text { Group } & \text { Initial assessment } & \text { Summative assessment } & \text { Progress } \\ \text { Mean } & \text { Control } & 8.08 & 8.15 & 0.07 \\ \text { Median } & \text { Exp. } & 8.50 & 9.10 & 0.55 \\ \text { Standard deviation } & \text { Control } & 8.70 & 8.95 & 0.15 \\ & \text { Exp. } & 1.28 & 1.21 & 0.76 \\ & & & 1.41 & 0.54\end{array}$

Students who were exposed to the instructional process based on the chosen mastery learning model were compared to the ones who were taught in a conventional manner. The initial assessment showed that the experimental and the control groups were quite similar (the difference between the two groups was 0.04 in favor of the experimental groups). To control the effect of this difference, progress (the difference between the summative assessments and the initial assessments) was analyzed to determine the effectiveness of the method. This way the performance of each student was compared to his initial results.

The students in the experimental groups made better progress than the students in the control groups: $4^{\text {th }}$ grade -0.91 (experimental group), 0.13 (control group), $p<0.05 ; 6^{\text {th }}$ grade -0.53 (experimental group), 0.07 (control group), $p<0.05$. The effect size was large: 0.88 ( $4^{\text {th }}$ grade) and 0.69 ( $6^{\text {th }}$ grade). The confidence interval $(95 \%)$ on the difference between means extended from 0.24 to 1.31 for $4^{\text {th }}$ grade and from 0.09 to 0.83 for $6^{\text {th }}$ grade. The Shapiro-Wilk indicators show a normal distribution: 0.94 $\left(4^{\text {th }}\right.$ grade) and $0.92\left(6^{\text {th }}\right.$ grade). 


\section{Discussion and Conclusion}

Based on the results presented above, we may say that the experiment conducted during the English lessons for the $4^{\text {th }}$ and $6^{\text {th }}$ graders was a successful one.

The use of regular formative assessments was very important to make the students more aware of the learning process and to help them overcome their learning difficulties. The supplementary activities were designed according to the students' needs and were based on Howard Gardner's theory of multiple intelligences (Gardner, 2006).

The mastery learning strategy that was applied in the experiment showed that the quality of the teaching-learning process improved considerably, and that the results of the students increased. In the $4^{\text {th }}$ grade, 16 out of 21 students succeeded to get a higher grade in the summative assessment compared to the results obtained in the initial assessment. In the $6^{\text {th }}$ grade, 22 out of 27 students succeeded to get a higher grade in the summative assessment compared to the results obtained in the initial assessment.

The advantages of applying this mastery learning strategy are to be taken into consideration.

1. The students became more aware of what they had to learn, and their learning was not superficial.

2. They were motivated because of the feedback provided and of the fact that the teacher gave them a second chance to show that they could learn.

Based on the observations made in class during the teaching-learning process and on the differences between the results obtained in the initial assessment and those obtained in the final assessment I can state that students became more determined to learn and to overcome their difficulties.

\section{Their results improved significantly.}

Table 10. Results of initial and summative assessments, $4^{\text {th }}$ grade

$\begin{array}{lll}\text { Student } & \begin{array}{l}\text { Initial assessment } \\ \text { A scale of } \mathbf{1} \text { to } \mathbf{1 0}\end{array} & \text { Sum } \\ 1 & 4.4 & \\ 2 & 6.0 & 6.4 \\ 3 & 4.4 & 6.2 \\ 4 & 7.0 & 5.6 \\ 5 & 4.8 & 9.2 \\ 6 & 7.7 & 7.6 \\ 7 & 4.6 & 8.0 \\ 8 & 8.4 & 5.6 \\ 9 & 9.4 & 8.2 \\ 10 & 6.5 & 9.2 \\ 11 & 8.4 & 8.7 \\ 12 & 7.7 & 9.6 \\ 13 & 8.2 & 8.7 \\ 14 & 10 & 9.8 \\ 15 & 9.0 & 10 \\ 16 & 8.7 & 8.4 \\ 17 & 7.0 & 9.2 \\ 18 & 8.2 & 7.5 \\ 19 & 8.0 & 8.0 \\ 20 & 8.0 & 9.0 \\ 21 & 6.5 & 9.5 \\ \text { Class average } & \mathbf{7 . 2 8} & 7.6 \\ & & \mathbf{8 . 1 9}\end{array}$


Table 11. Results of initial and summative assessments, $6^{\text {th }}$ grade

\begin{tabular}{|c|}
\hline Student \\
\hline 1 \\
\hline 2 \\
\hline 3 \\
\hline 4 \\
\hline 5 \\
\hline 6 \\
\hline 7 \\
\hline 8 \\
\hline 9 \\
\hline 10 \\
\hline 11 \\
\hline 12 \\
\hline 13 \\
\hline 14 \\
\hline 15 \\
\hline 16 \\
\hline 17 \\
\hline 18 \\
\hline 19 \\
\hline 20 \\
\hline 21 \\
\hline 22. \\
\hline 23 \\
\hline 24 \\
\hline 25 \\
\hline 26 \\
\hline 27 \\
\hline
\end{tabular}

Class average

Initial assessment
A scale of $\mathbf{1}$ to $\mathbf{1 0}$
6.35
8.05
8.35
9.2
8.75
9.3
7.4
8.8
9.05
8.6
9.2
7.5
5.5
7.0
5.1
8.6
8.5
6.8
7.55
8.35
10
7.1
7.15
10
9.9
8.6
8.75
8.12

8.12

\section{Summative assessment}

6.95

9.45

9.25

9.75

9.75

9.6

8.7

8.5

9.45

7.45

10

6.5

8.5

7.55

5.5

9.4

9.1

7.4

7.85

8.85

10

8.05

7.55

10

10

9.1

9.45

8.98

One of the results that the researcher did not expect was to see a change in the learners' attitude regarding the participation in the English classes and the willing fulfillment of every learning task. This fact was based on in-class observations and on the discussions the researcher had with the students who were eager to have another class because they really enjoyed working more (when they had to complete remedial and enrichment activities they were really enthusiastic because the activities were based on playing a lot of games, watching videos, drawing, colouring, and working in groups). Another reason was to take a test right after completing a learning task because they wanted to demonstrate what they had learnt.

To show the efficacy of mastery learning models, the results of the current study were compared to the findings of some previous studies.

Table 12. Characteristics of selected studies

\begin{tabular}{|c|c|c|c|c|}
\hline Study & Subject & $\begin{array}{l}\text { Level of } \\
\text { experimental group }\end{array}$ & $\begin{array}{l}\text { Level of control } \\
\text { group }\end{array}$ & $\begin{array}{l}\text { Implemented teaching } \\
\text { strategy in the experimental } \\
\text { group }\end{array}$ \\
\hline Current study & English & $\begin{array}{l}\text { Primary and } \\
\text { secondary school } \\
\text { 4th and 6th grades }\end{array}$ & $\begin{array}{l}\text { Primary and } \\
\text { secondary school } \\
\text { 4th and 6th grades }\end{array}$ & mastery learning strategy \\
\hline $\begin{array}{l}\text { Mehar \& Kanwar } \\
\text { (2019) }\end{array}$ & English & $\begin{array}{l}\text { High school } \\
\text { 9th grade }\end{array}$ & $\begin{array}{l}\text { High school } \\
\text { 9th grade }\end{array}$ & $\begin{array}{l}\text { online mastery learning } \\
\text { strategy }\end{array}$ \\
\hline
\end{tabular}




\begin{tabular}{|c|c|c|c|c|c|c|}
\hline Birhan (2018) & Writing Skills & $\begin{array}{l}\text { University } \\
\text { students) }\end{array}$ & (first-year & $\begin{array}{l}\text { University } \\
\text { students) }\end{array}$ & (first-year & mastery learning strategy \\
\hline Moumer & English & $\begin{array}{l}\text { High school } \\
\text { 10th grade }\end{array}$ & & $\begin{array}{l}\text { High school } \\
\text { 10th grade }\end{array}$ & & mastery learning model \\
\hline $\begin{array}{l}\text { Mayanchi, Anya, \& } \\
\text { Kainuwa (2017) }\end{array}$ & Maths & $\begin{array}{l}\text { Senior } \\
\text { school }\end{array}$ & secondary & $\begin{array}{l}\text { Senior } \\
\text { school }\end{array}$ & secondary & mastery learning \\
\hline $\begin{array}{l}\text { Mitee \& Obaitan } \\
(2015)\end{array}$ & Chemistry & $\begin{array}{l}\text { Senior } \\
\text { school }\end{array}$ & secondary & $\begin{array}{l}\text { Senior } \\
\text { school }\end{array}$ & secondary & mastery learning method \\
\hline Kazu et al. (2005) & $\begin{array}{l}\text { Information } \\
\text { Technologies }\end{array}$ & University & & University & & mastery learning model \\
\hline
\end{tabular}

Mehar and Kanwar (2019), in their research Effect of Online Mastery Learning Strategy on Achievement in English in Relation to Cognitive Ability, investigated the outcomes of implementing mastery learning strategies in English language teaching with regard to learning English in relation to cognitive abilities. The participants in this study were 120 students in $9^{\text {th }}$ grade from two private schools in Uttar Pradesh, India. A pre-test and a post-test were administered. The experimental group was taught using an online mastery learning strategy while the control group was taught conventionally. The findings of the study showed that the achievement of students in the experimental group was higher than the achievement of the students in the control group. At the same time, there was a "significant interaction effect between online mastery learning strategies and cognitive ability on achievement in English" (Mehar \& Kanwar, 2019, p. 837)

In his article, Effects of Mastery Learning Instruction on Engineering Students' Writing Skills Development and Motivation, Birhan (2018) aimed to emphasize the results of implementing a mastery learning strategy in order to influence students' academic writing and motivation while learning English as a foreign language. The participants in this study were 105 first-year students (53 students in the experimental group and 52 students in the control group). The outcomes of this research indicated a statistically significant difference between the two groups. As a result of using a mastery learning method, students in the experimental group succeeded in improving their writing skills and were more motivated than the students in the control group.

Abu Moumer (2017), in her research The Effectiveness of a Mastery Learning Model on English Grammar Learning and SelfEfficacy of the Tenth Graders, showed that students learn English grammar better when the instructional process is based on a mastery learning model. The study was conducted with 69 students in $10^{\text {th }}$ grade (36 students in the experimental group and 33 in the control group). The results obtained by the students in the experimental group were better than those obtained by the students in the control group. The findings revealed that the differences in terms of mean scores between the two groups were statistically significant.

Mayanchi, Anya, and Kainuwa (2017), in their research Effects of Mastery Learning and Problem Solving Methods of Teaching on Students' Academic Performance in Mathematics in Zamfara State, emphasized the efficiency of using mastery learning methods in teaching mathematics. The participants in this study were 450 secondary school students. A pre-test and a post-test were administered. The results obtained showed that students in the experimental group had better outcomes than students in the control group who were exposed to traditional teaching methods.

The study conducted by Mitee and Obaitan (2015), Effect of Mastery Learning on Senior Secondary School Students' Cognitive Learning Outcome in Quantitative Chemistry, analyzed the effects of a mastery learning approach on improving the cognitive outcomes in learning chemistry. The aim of this study was to reveal how mastery learning methods influence the performance of students in the above-mentioned subject. There were 401 senior secondary school students who took part in this study. A pre-test and a post-test were applied. The outcomes showed that mastery learning methods are efficient with respect to improving students' performance in learning chemistry. 
The study conducted by Kazu et al. (2005), The Effects of Mastery Learning Model on the Success of the Students Who Attended "Usage of Basic Information Technologies" Course, aimed at determining the effects of a mastery learning model implemented in a course regarding the use of Microsoft Word and Microsoft Excel. The outcomes of this study showed a statistically significant difference in the results obtained in the final test for the experimental group as compared to the control group. The researchers stated that "the mastery learning model affected the success and achievement of the students positively" (Kazu et al., 2005, p. 241).

\section{Statistical analysis}

To estimate the effect size, Hedge's $g$ coefficient was calculated. Similar to Cohen's $d$ coefficient, a $0.2-0.5$ value shows a small size effect, a $0.5-0.8$ value shows a medium effect size, and a 0.8 value or higher shows a large effect size (Cohen, 1988).

A positive value of Hedge's coefficient showed that the implemented mastery learning strategies were efficient.

Figure 2. Forest plot of average effect sizes

\begin{tabular}{|c|c|c|c|c|c|c|c|}
\hline \multirow{2}{*}{ Study name } & \multicolumn{7}{|c|}{ Statistics for each study } \\
\hline & $\begin{array}{l}\text { Hedges's } \\
\text { g }\end{array}$ & $\begin{array}{l}\text { Standard } \\
\text { error }\end{array}$ & Variance & $\begin{array}{c}\text { Lower } \\
\text { limit }\end{array}$ & $\begin{array}{l}\text { Upper } \\
\text { limit }\end{array}$ & Z-Value & p-Value \\
\hline KAZU (2005) & 0,100 & 0,219 & 0,048 & $-0,330$ & 0,529 & 0,456 & 0,648 \\
\hline MITEE \& OBAITAN (2015) & 1,492 & 0,113 & 0,013 & 1,271 & 1,713 & 13,225 & 0,000 \\
\hline ABU MOUMER (2017) & 1,492 & 0,270 & 0,073 & 0,962 & 2,021 & 5,525 & 0,000 \\
\hline MAYANCH et al. (2017) & 0,774 & 0,119 & 0,014 & 0,540 & 1,008 & 6,478 & 0,000 \\
\hline BIRHAN (2018) & 0,856 & 0,203 & 0,041 & 0,458 & 1,253 & 4,223 & 0,000 \\
\hline MEHAR \& KANWAR (2019) & 0,915 & 0,191 & 0,036 & 0,541 & 1,289 & 4,797 & 0,000 \\
\hline Current study 4th grade & 0,475 & 0,301 & 0,090 & $-0,114$ & 1,064 & 1,579 & 0,114 \\
\hline Current study 6th grade & 0,376 & 0,276 & 0,076 & $-0,165$ & 0,917 & 1,363 & 0,173 \\
\hline
\end{tabular}

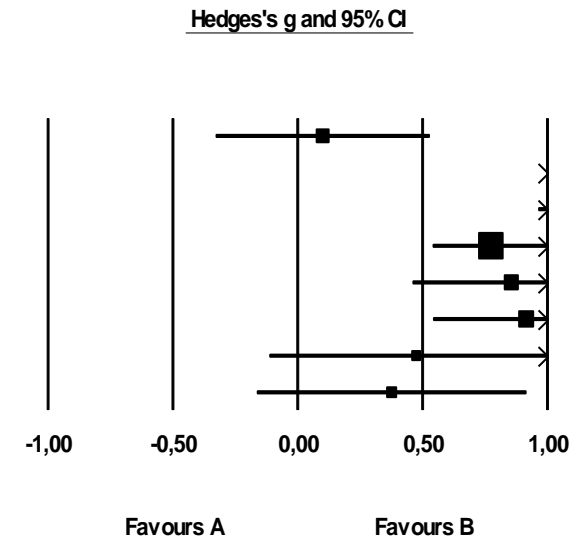

Figure 3. Funnel plot of publication bias

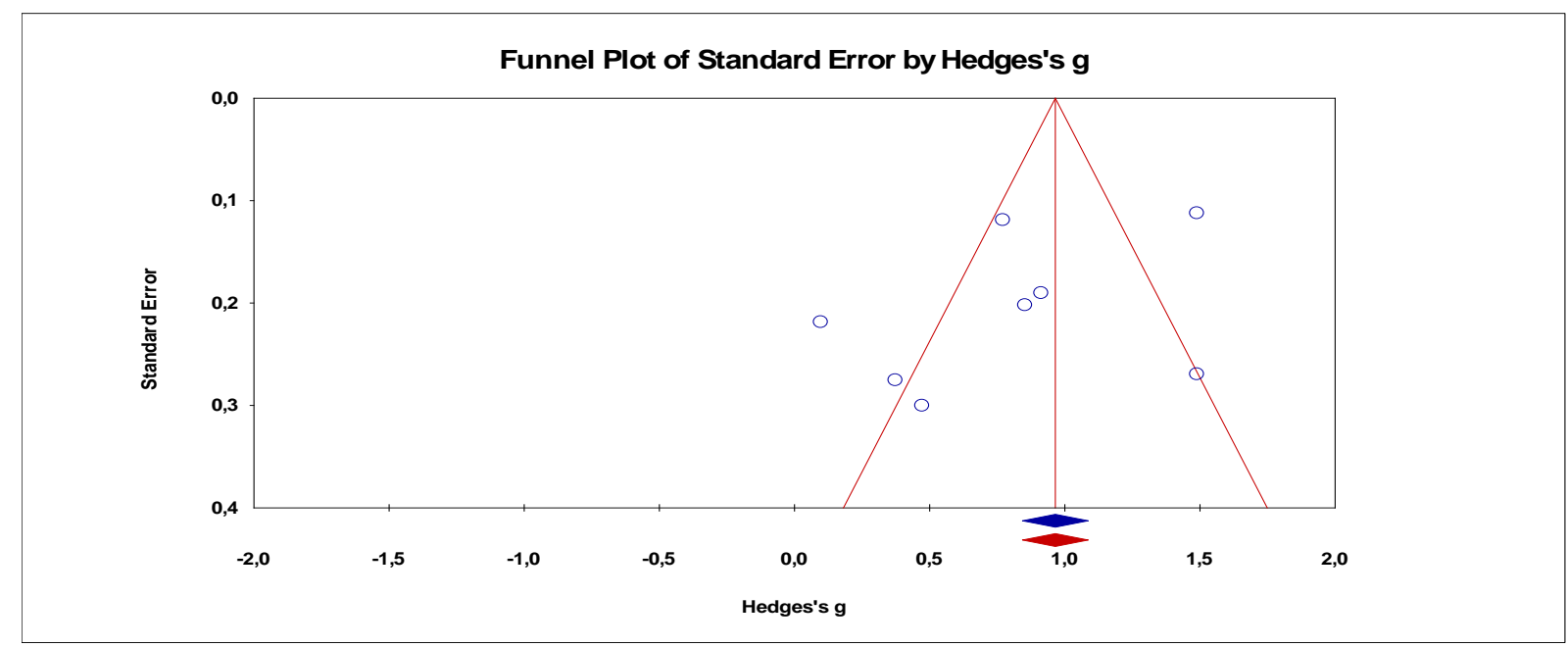




\section{Recommendations}

Even though the number of students was relatively small, and the experiment was not conducted over a long period of time, we may say that the results of this study represent a stepping stone in our educational system. Based on them and on the strategy that the researcher presented, teachers may develop their own teaching-learning strategies which may help them offer their students a chance for a great improvement of their grades.

Mastery learning strategies should be implemented in all subjects nationwide and the positive outcomes of all studies regarding the implementation of mastery learning models should be made more visible in the Romanian education system.

There should be a national training program that will inform and prepare teachers for using mastery learning techniques in their classes. This can also be acquired by creating some good practice guides that focus on giving examples of mastery learning strategies for all subjects and on the means used to be implemented in schools.

At first, this kind of strategies should be implemented in a pilot program involving several schools from both rural and urban areas to see if the learning model can be used on a large scale and if it has the expected outcomes as opposed to the outcomes obtained in a conventional teaching-learning process.

Another recommendation would be to create an online platform for teachers to debate different topics related to mastery learning, to share ideas and experiences, and to benefit from different types of methods and tools that have led to mastery learning in different classes.

In order to facilitate students' access to knowledge, they should also be registered on an online platform where they could complete more learning activities developed according to their characteristics and individual needs that would help them overcome the difficulties they might encounter in learning. Working on an online platform would significantly reduce the time spent in class for completing remedial or enrichment activities. Also, the use of technology in learning might be of great interest for students.

One last recommendation would be to develop a national syllabus that will allow students and teachers to be engaged in an efficient teaching-learning process and not in one that might require a somehow superficial coverage due to the extensive contents and to the lack of necessary time. 


\section{References}

Abu Moumer, R.N.M. (2017). The Effectiveness of a Mastery Learning Model on English Grammar learning and Self-Efficacy of the Tenth Graders. MA thesis. The Islamic University of Gaza.

Amirrudin, M.H., \& Zainudin, F.L. (2015). The effects of a mastery learning strategy on knowledge acquisition among Aboriginal students: An experimental approach. International Journal of Vocational Education and Training Research, 1(2), 22-26.

Anania, J. (1983). The influence of instructional conditions on student learning and achievement. Evaluation in Education: An International Review Series, 7(1), 1-92.

Anania, J. (1982). The Effects of Quality of Instruction on the Cognitive and Affective Learning of Students. Doctoral dissertation. University of Chicago, 1981. Dissertation Abstracts International, 42, 4269A.

Aviles, C.B. (2001). A study of mastery learning versus non-mastery learning instruction in an undergraduate social work policy classroom. Retrieved July 1, 2020 from https://eric.ed.gov/?id=ED449413

Birhan, A.T. (2018). Effects of Mastery Learning Instruction on Engineering Students' Writing Skills Development and Motivation. Journal of Language and Education, 4, 20-30.

Block, J.H. \& Burns, R.B. (1976). Mastery learning. Review of Research in Education, 4, 3-49.

Bloom, B.S. (1984). The 2-sigma problem: The search for methods of group instruction as effective as one-to-one tutoring. Educational Researcher, 13(6), 4-16.

Bloom, B.S. (1968). Learning for mastery: Instruction and curriculum. Evaluation Comment, 1(1), Los Angeles, CA: University of California, 1-12. (ERIC ED 053 419)

Bloom, B.S. (1956). Taxonomy of Educational Objectives: Cognitive Domain, New York, NY: Longman.

Bunescu, V. (1995). Învățarea deplină. Teorie și practică, București, România: Editura Didactică și Pedagogică.

Burke, A.J. (1984). Students' Potential for Leaning Contrasted under Tutorial and Group Approaches to Instruction. Doctoral dissertation, University of Chicago, 1983. Dissertation Abstracts International, 44, $2025 \mathrm{~A}$.

Carroll, J. B. (1963). A model of school learning. Teachers College Record, 64(8), 723-733.

Cohen, J. (1988). Statistical Power Analysis for the Behavioral Sciences (2nd edition). Hillsdale, N.J.: Routledge.

Elaldı, Ş. (2016). The effect of mastery learning model with reflective thinking activities on medical students' academic achievement: An experimental study. Journal of Education and Training Studies, 4(5), 30-40.

European Commission. (2019). Education and Training Monitor 2019. Romania. Retrieved June 10, 2020 from https://ec.europa.eu/education/sites/education/files/document-library-docs/et-monitor-report-2019-romania_en.pdf

European Commission. (2015). Education and Training Monitor 2015. Retrieved June 20, 2020 from https://ec.europa.eu/assets/eac/education/tools/docs/2015/monitor15-vol-2_en.pdf

Gardner, H. (2006). Multiple Intelligences: New Horizons in Theory and Practice. New York: Basic Books.

Hill-Miller, P.L. (2011). Different Approach, Different Results: A Study of Mastery Learning Instruction in a Developmental Reading Class at an Urban Community College. A PhD dissertation. Charlotte: University of North Carolina. 
Jinga, I. \& Negreț, I. (1994). Învățarea eficientă. O abordare teoretică și două ghiduri practice pentru educatori și elevii lor, București, România: Editis.

Kazu, I.Y., Kazu, H., \& Ozdemir, O. (2005). The effects of mastery learning model on the success of the students who attended "Usage of Basic Information Technologies" course. Educational Technology and Society, 8(4), 233-243.

Leyton, F.S. (1983). The Extent to Which Group Instruction Supplemented by Mastery of the Initial Cognitive Prerequisites Approximates the Learning Effectiveness of One-to-One Tutorial Methods. Doctoral dissertation, University of Chicago, 1983. Dissertation Abstracts International, 44, 974A.

Mayanchi, L.M., Anya, C.A., \& Kainuwa, M.A. (2017). Effects of mastery learning and problem solving methods of teaching on students' academic performance in mathematics in Zamfara state. International Journal of Educational Research and Technology, 8 (3), 1-8.

Mehar, R., \& Kanwar, S. (2019). Effect of online mastery learning strategy on achievement in English in relation to cognitive ability. International Journal of Scientific \& Technology Research, 8 (8), 837-845.

Ministry of National Education. (2018). A Report on Undergraduate Education System in Romania. Retrieved July10, 2020 from https://www.edu.ro/sites/default/files/Raport\%20privind\%20starea\%20\%C3\%AEnv\%C4\%83\%C8\%9B\%C4\%83m\%C3\%A2 ntului\%20preuniversitar\%20din\%20Rom\%C3\%A2nia_2017-2018_0.pdf

Mitee, T.L., \& Obaitan, G.N. (2015). Effect of mastery learning on senior secondary school students' cognitive learning outcome in quantitative chemistry. Journal of Education and Practice, 6(5), 34-38.

Moyosore, O.A. (2015). The effect of formative assessment on students' achievement in secondary school mathematics. International Journal of Education and Research, 3(10), 481-490.

Radu, I.T. (2007). Evaluarea în procesul didactic. București, România: Editura Didactică și Pedagogică.

Rintaningrum, R. (2018). A model of school learning: The use of Carroll's model of foreign language learning. International Symposium For Modern School Development, Social Science And Applied Technologies 2 (ISMOSAT). Indonesia. Retreived from

https://www.researchgate.net/publication/324221923_A_Model_of_School_Learning_The_use_of_Carroll\%27s_Model_of_ Foreign_Language_Learning

Sooyoung, K. (2005). The relationship between enactive mastery experiences and online- course self-efficacy (OCSE). Retrieved July 10, 2020 from https://eric.ed.gov/?id=ED492291

Thompson, J.A. \& Grabau, L.J. (2005). A la carte grading: Providing students opportunities to determine their own paths to success. Journal of Natural Resources and Life Sciences Education, 33 (1), 92-97.

Washburne, C.W. (1925). Burk's individual system as seveloped at Winnetka. In G.M. Whipple (ed.). Adapting the Schools to Individual Differences. Bloomington, IL: Public School Publishing Company.

Washburne, C.W., Vogel, M., \& Gray, W.S. (1926). Results of Practical Experiments in Fitting Schools to Individuals: A Survey of the Winnetka Public Schools under a Subvention from the Commonwealth Fund. Bloomington, IL: Public School Publishing Company. 